\title{
Imaging tropical peatlands in Indonesia using ground-penetrating radar (GPR) and electrical resistivity imaging (ERI): implications for carbon stock estimates and peat soil characterization
}

\author{
X. Comas ${ }^{1}$, N. Terry ${ }^{2}$, L. Slater ${ }^{2}$, M. Warren ${ }^{3}$, R. Kolka ${ }^{4}$, A. Kristiyono ${ }^{5}$, N. Sudiana ${ }^{5}$, D. Nurjaman ${ }^{5}$, and \\ T. Darusman 6 \\ ${ }^{1}$ Department of Geosciences, Florida Atlantic University, Davie, FL 33314, USA \\ ${ }^{2}$ Department of Earth \& Environmental Sciences, Rutgers University - Newark, Newark, NJ 07102, USA \\ ${ }^{3}$ USDA Forest Service, Northern Research Station, Durham, NH 03824, USA \\ ${ }^{4}$ USDA Forest Service, Northern Research Station, Grand Rapids, MN 55744, USA \\ ${ }^{5}$ Indonesian Agency for Assessment and Application of Technology (BPPT), Jakarta 10340, Indonesia \\ ${ }^{6}$ Puter Foundation, Bogor, Indonesia \\ Correspondence to: X. Comas (xcomas@fau.edu)
}

Received: 21 September 2014 - Published in Biogeosciences Discuss.: 6 January 2015

Revised: 17 April 2015 - Accepted: 21 April 2015 - Published: 21 May 2015

\begin{abstract}
Current estimates of carbon (C) storage in peatland systems worldwide indicate that tropical peatlands comprise about $15 \%$ of the global peat carbon pool. Such estimates are uncertain due to data gaps regarding organic peat soil thickness, volume and $\mathrm{C}$ content. We combined a set of indirect geophysical methods (ground-penetrating radar, GPR, and electrical resistivity imaging, ERI) with direct observations using core sampling and $\mathrm{C}$ analysis to determine how geophysical imaging may enhance traditional coring methods for estimating peat thickness and C storage in a tropical peatland system in West Kalimantan, Indonesia. Both GPR and ERI methods demonstrated their capability to estimate peat thickness in tropical peat soils at a spatial resolution not feasible with traditional coring methods. GPR is able to capture peat thickness variability at centimeter-scale vertical resolution, although peat thickness determination was difficult for peat columns exceeding $5 \mathrm{~m}$ in the areas studied, due to signal attenuation associated with thick clay-rich transitional horizons at the peat-mineral soil interface. ERI methods were more successful for imaging deeper peatlands with thick organomineral layers between peat and underlying mineral soil. Results obtained using GPR methods indicate less than $3 \%$ variation in peat thickness (when compared to coring methods) over low peat-mineral soil interface gradients (i.e., below $0.02^{\circ}$ ) and show substantial impacts in $\mathrm{C}$
\end{abstract}

storage estimates (i.e., up to $37 \mathrm{MgC} \mathrm{ha}^{-1}$ even for transects showing a difference between GPR and coring estimates of $0.07 \mathrm{~m}$ in average peat thickness). The geophysical data also provide information on peat matrix attributes such as thickness of organomineral horizons between peat and underlying substrate, the presence of buried wood, buttressed trees or tip-up pools and soil type. The use of GPR and ERI methods to image peat profiles at high resolution can be used to further constrain quantification of peat $\mathrm{C}$ pools and inform responsible peatland management in Indonesia and elsewhere in the tropics.

\section{Introduction}

Globally, tropical peatlands are estimated to store $89 \mathrm{PgC}$, equivalent to about $1 / 10$ of the current atmospheric carbon pool (Page et al., 2011). Indonesia contains the largest area of the world's tropical peatlands, with estimates ranging from 14.9 Mha (Ritung et al., 2011) to 21 Mha (Wahyunto et al., 2003, 2004; Page et al., 2011). Indonesian peat swamps have been globally significant carbon sinks over the past 15000 years (Dommain et al., 2014); however, vast areas of Indonesian peatlands are becoming large, long-term sources of greenhouse gases (primarily $\mathrm{CO}_{2}$ ) for the atmosphere due to 
deforestation, drainage and/or peat fires (Page et al., 2002; van der Werf et al., 2009). In a recent overview of carbon distribution based on a 2008 inventory, Indonesia was considered the largest source of $\mathrm{CO}_{2}$ emissions from degrading peat worldwide, with values exceeding other large producers such as China and the United States by almost 1 order of magnitude (Joosten, 2009). Therefore, Indonesia's peatlands are considered "hotspots" for greenhouse gas emissions, and are priority areas for climate mitigation strategies including programs such as Reducing Emissions from Deforestation and Forest Degradation (or REDD+). However, data deficiencies on area, depth, volume and carbon density of Indonesian peatlands contribute to large uncertainties in carbon pools and fluxes at local to national scales. Such lack of information may also contribute to management decisions which exacerbate greenhouse emissions from peatland degradation. Refinement of estimates on depth and volume of peat soils in Indonesia is the focus of this paper.

Current estimates of $\mathrm{C}$ storage in global peatlands range between 528 and $694 \mathrm{Pg} \mathrm{C}$ (Hooijer et al., 2006; Yu et al., 2010). Tropical and subtropical systems are estimated to comprise about $15 \%$ of the global peat carbon pool, with Indonesia estimated to contain about $65 \%$ of tropical peat carbon (Page et al., 2011). However, these estimates are tentative due to uncertainties in peat thickness, volume and $\mathrm{C}$ density at large spatial scales. Estimating peat carbon storage requires accurate volume measurements calculated from peat area and thickness. Page et al. (2011) calculated peat volume for Indonesia using a mean peat depth of $5.5 \mathrm{~m}$, which was based on very few geographically biased data considering the scale at which the mean depth estimate was applied: $206950 \mathrm{~km}^{2}$ throughout Indonesian Borneo (Kaliman$\tan$ ), Sumatra and Papua. Perhaps the most accurate peat volume measurements published at a local scale in Indonesia were reported by Jaenicke et al. (2008), who modeled peat depth using a combination of 542 discrete field measurements from direct coring, surface elevation models, satellite imagery and spatial interpolation across four peat domes in Central Kalimantan. Despite the large number of direct measurements of peat thickness, the uncertainty in carbon storage estimates ranged from 13 to $25 \%$, which the authors attributed to bedrock unconformities not considered in the models of peat volume derived from relationships between surface elevation and peat thickness (Jaenicke et al., 2008). Most current efforts to model peat depth are based on the assumption that peat deposits occur in uniform biconvex formations, despite evidence from field measurements indicating considerable buried topography under the peat in some areas such as riverbeds and levees. For example, surveys have shown mineral substrate topography changing as much as $2 \mathrm{~m}$ within single transects (of less than $1 \mathrm{~km}$ ) across several peat domes in Borneo (Konsultant, 1998; Dommain et al., 2010).

Near-surface geophysical methods, particularly groundpenetrating radar (GPR), have been used extensively in bo- real peatland systems to explore many aspects related to peat development and stratigraphy (Comas and Slater, 2009). Recent studies of peat thickness and peat basin volume using GPR include a variety of field sites and typically indicate discrepancies in peat volume estimates of about $20 \%$ when compared to traditional direct methods such as coring (Rosa et al., 2009; Parsekian et al., 2012; Parry et al., 2014). Electrical resistivity imaging (ERI) has also been used in boreal systems for investigating several aspects of peatland stratigraphy and hydrogeology (Meyer, 1989; Slater and Reeve, 2002; Comas et al., 2004, 2011); however, no studies to our knowledge have focused on peat thickness characterization using ERI.

Although numerous studies have used GPR and ERI methodologies to study peatland attributes in boreal systems, the use of these techniques in tropical systems has not been reported. Although differences in peat types, terrain and/or vegetation cover between boreal and tropical systems must be considered, similarities in peat electromagnetic and electrical properties are anticipated, supporting the use of GPR and ERI methods for mapping tropical peatlands and underlying buried topography.

Here we report the use of a combination of GPR and ERI methods to obtain high-resolution profiles of peat layers in West Kalimantan, Indonesia. The objectives of this study were to (1) test the potential of GPR and ERI for estimating peat thickness in a non-invasive and spatially continuous way at a resolution previously unreported for tropical peatlands and (2) evaluate whether certain information on geological settings and/or peat composition can be drawn from these methods. The ultimate aim of the approach presented here is to demonstrate the applicability of geophysical methods to investigate tropical peat systems, and to highlight potential for improved accuracy of peat $\mathrm{C}$ storage estimates relative to estimates derived from traditional coring methods. Advancing this knowledge could help to inform peatland management decisions in Indonesia and improve assessments of peat subsidence and $\mathrm{C}$ stock changes.

\section{Methods}

\subsection{Field sites}

Two peatland sites located in the West Kalimantan Province of Indonesia were chosen for this study: Tanjung Gunung (Sejahtera village, North Kayong Regency); and Pelang (Pelang village, Ketapang Regency). Both sites had been previously investigated by USFS (United States Forest Service) collaborators and were known to contain variable peat thickness and multiple landcover types, while providing relatively easy access. The Tanjung Gunung site (hereafter referred to as TG) is adjacent to Gunung Palung National Park and its natural resources have been heavily exploited by the local community for decades. Within the TG site, two areas along 
the same peat formation were studied: a thinned, degraded forest (TG1) and a mature rubber plantation which is located at the edge of the peat formation (TG2). The physiographic terrain at TG is a $6 \mathrm{~km}$ wide swamp peatland known as Mendawai, MDW (RePPProT, Regional Physical Planning Programme for Transmigration, 1990) that is characterized by shallow peat. Kahayan (KHY) peaty alluvial plains are also formed along the seaward edges of MDW (inset in Fig. 1). Although the two selected study sites (TG1 and TG2) are only approximately $1 \mathrm{~km}$ apart and are both situated in a transition zone between KHY and MDW ecosystems, differences exist in terms of thickness of peat and organomineral transitional layers and water table depth. While TG1 is characterized by MDW properties (i.e., shallow peat swamps), TG2 is characterized by a mixture of MDW and KHY properties, including landforms such as coalescent estuarine and riverine plains with lithologies that include alluvium and marine sediments.

At the Pelang forest site (hereafter referred to as P), two areas along the same peat formation were also studied: a thinned, degraded forest occurring on approximately 4-5 m deep peat (P1), which transitioned to a cleared area covered in secondary ferns and grasses, and a degraded forest (P2) heavily used by a local village occurring on very deep peat (>9 m). Compared to the Tanjung Gunung sites (TG1 and TG2), Pelang forest sites are characterized by extensive peatlands over about $20 \mathrm{~km} \times 20 \mathrm{~km}$ (inset in Fig. 1), forming three types of peat ecosystems: (a) Klaru (KLR) or permanently water logged peaty floodplains; (b) Gambut (GBT) or deeper dome-shaped peat swamp; and (c) Mendawai (MDW) or shallower peat swamp. Similar to the previous sites at TG, Kahayan (KHY) peaty alluvial plains are also formed along the seaward edges of MDW (Fig. 1). Two measurement sites were also selected at this location and included P1 (located at a boundary zone of GBT and MDW), whereas site P2 is located within GBT. The results of 2-D resistivity measurements described below show significant differences in these two ecosystems. Additional specifications for each study site are summarized in Table 1, including a description of the landcover, average peat depth and land system after RePPProT (1990).

\subsection{Ground-penetrating radar}

Ground-penetrating radar (GPR) is a fast, reliable, and inexpensive geophysical method for non-destructive mapping of shallow subsurface features in peatlands at scales ranging from kilometers for geological features influencing peatland hydrology such as eskers (Comas et al., 2011), to centimeters for determination of bubble distribution in peat blocks at the laboratory scale (Comas and Slater, 2007). The GPR technique involves the transmission of short pulses of high frequency electromagnetic (EM) energy into the ground, and measurement of the energy reflected from interfaces between subsurface materials with contrasting electrical properties. In

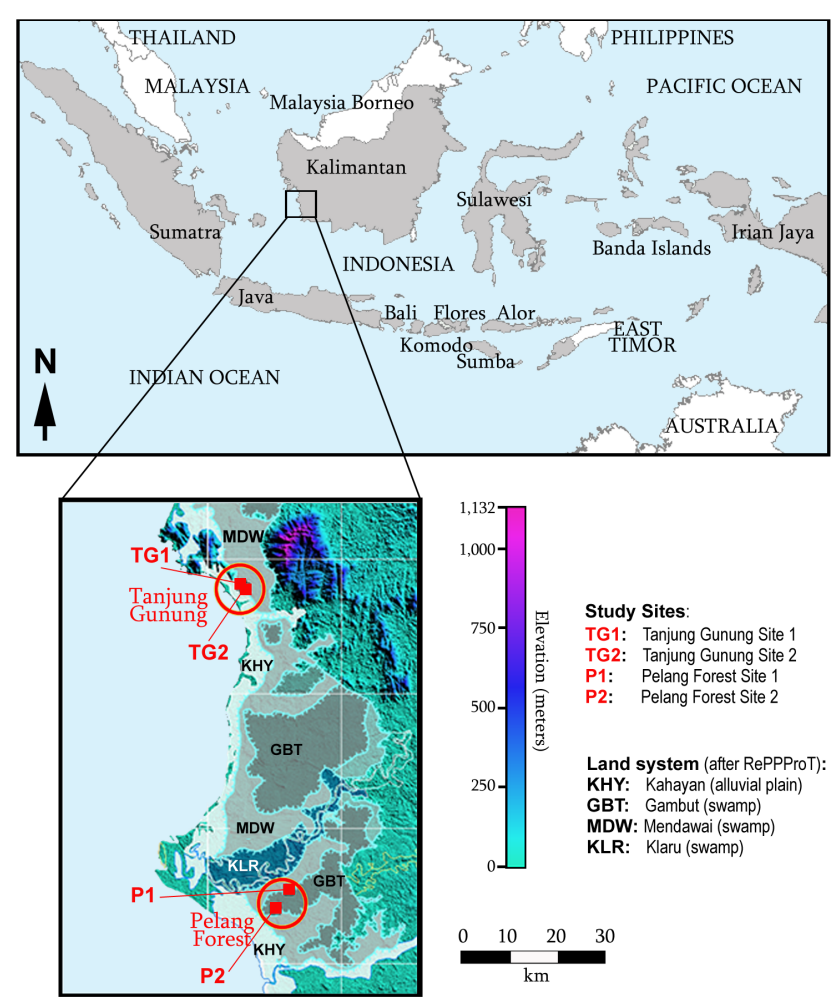

Figure 1. Schematic showing the location of the study sites in West Kalimantan, Indonesia. A total of four sites were investigated: Tanjung Gunung Site 1 (TG1) and Site 2 (TG2), and Pelang forest Site 1 (P1) and Site 2 (P2). Inset shows details about the land system as classified after RePPProT (1990): Kahayan (KHY) mainly characterized by alluvial plains; and Gambut (GBT), Mendawai (MDW) and Klaru (KLR) characterized by swamps. Color scale indicates elevation above sea level.

the most common deployment, one antenna (the transmitter) radiates short pulses of EM waves, and the other antenna (the receiver) measures the reflected signal as a function of time. Reflections are primarily caused by changes in water content, which in turn are determined by sediment type and soil density. Reliable estimates of EM wave velocity $(v)$, primarily controlled by relative dielectric permittivity $\varepsilon_{\mathrm{r}(\mathrm{b})}$, are required to convert the EM wave travel times recorded by GPR to depths of significant reflectors. Due to the high water content of peat soils, the $\varepsilon_{\mathrm{r}(\mathrm{b})}$ of peat is very high compared to inorganic mineral soils, reaching values of 50-70 depending on peat type. When $\varepsilon_{\mathrm{r}(\mathrm{b})}$ is generally well constrained from velocity analysis, estimation of peat depth is typically accurate to within $\sim 20 \mathrm{~cm}$ (Parsekian et al., 2012).

GPR surveys were performed using a MALÅ RAMAC system with 50,100 and $200 \mathrm{MHz}$ antennas, with the $100 \mathrm{MHz}$ antennas proving the best compromise between depth of investigation and resolution. Malfunctioning of the $50 \mathrm{MHz}$ antennas towards the end of the campaign prevented testing depth of penetration for this frequency at study sites with thicker peat columns. The spacing between traces was 
Table 1. Summary of field sites including landcover, peat depth (from direct core measurements) and land system after RePPProT (Regional Physical Planning Programme for Transmigration 1990).

\begin{tabular}{|c|c|c|c|c|}
\hline Study site & Landcover & Peat depth (m) & Land system & Description \\
\hline $\begin{array}{l}\text { Tanjung Gunung } 1 \\
\text { (TG1) }\end{array}$ & Thinned forest & $3.9-4.3$ & $\begin{array}{l}\text { KHY-MDW transition } \\
\text { (MDW) }\end{array}$ & Shallow peat swamps \\
\hline $\begin{array}{l}\text { Tanjung Gunung } 2 \\
\text { (TG2) }\end{array}$ & Rubber plantation & $0.3-3.5$ & $\begin{array}{l}\text { KHY-MDW transition } \\
\text { (KHY-MDW) }\end{array}$ & $\begin{array}{l}\text { Shallow peat swamps-estuarine/ } \\
\text { riverine plains }\end{array}$ \\
\hline $\begin{array}{l}\text { Pelang forest } 1 \\
\text { (P1) }\end{array}$ & Disturbed forest & $4.0-5.0$ & $\begin{array}{l}\text { GBT-MDW } \\
\text { boundary }\end{array}$ & $\begin{array}{l}\text { Deep peat swamp- } \\
\text { shallow peat swamp }\end{array}$ \\
\hline $\begin{array}{l}\text { Pelang forest } 2 \\
\text { (P2) }\end{array}$ & Thinned forest & $>9.0$ & GBT & Deep peat swamp \\
\hline
\end{tabular}

$0.2 \mathrm{~m}$ and 16 stacks (or replicates) were used for each trace. Two types of surface GPR surveys were performed: (1) common-offset surveys, where both transmitter and receiver antennas are kept at a constant distance as they are moved along transects and (2) common mid-point (CMP) measurements where transmitter and receiver are separated incrementally to larger distances. Common-offset surveys were used for subsurface imaging purposes (since profiles resemble a geological cross-section where depth is expressed as a travel time of the EM wave), whereas CMPs were used for velocity estimation.

\subsection{Electrical resistivity imaging}

ERI is a method for generating images of the variation in electrical resistivity in either two or three dimensions below a line or grid of electrodes placed at the Earth's surface. Data are acquired by measuring the voltage differences between electrode pairs in response to current injection between additional electrode pairs. Numerical methods are used to solve the Poisson equation relating the theoretical voltages at the electrodes to the distribution of resistivity in the subsurface. Inverse methods are used to find a model for the subsurface resistivity structure that is consistent with the recorded field data and also conforms to model constraints imposed (typically the resistivity structure varies smoothly). The resulting resistivity structure describes variations in the ability of subsurface soils and rocks to conduct an electrical current. The resistivity is strongly controlled by water content, chemical composition of the pore water and soil surface area/grain particle size distribution.

Electrical resistivity imaging was conducted using a fourelectrode Wenner configuration with both 1 and $2 \mathrm{~m}$ electrode spacing. This spacing provided maximum imaged depths of about $16 \mathrm{~m}$. The imaging depth was estimated from the model resolution matrix (Menke, 1989; see Binley and Kemna, 2005 for further details) that depicted relatively good resolution within this region when compared with the rest of the modeling domain. Measurements were performed using an ARES (Automatic Resistivity System) G4 2A resistivity meter with a 48-multi-electrode switch box. Inversion and forward simulations were performed with R2 software written by Andrew Binley (Lancaster University). R2 uses an iterative finite-element method to estimate resistivity values at user-specified element locations in a finite-element mesh. The regularization was based on the popular smoothness constrained approach used to solve for the minimum structure resistivity model that satisfies the data constraints.

A triangular mesh with a characteristic length one-quarter of the spacing at the electrodes and growing larger toward the edges (to account for decaying model resolution) was built using Gmsh, a three-dimensional finite-element mesh program (Geuzaine and Remacle, 2009). R2 requires an estimate of the error associated with each data point for convergence to be evaluated. For this purpose, it is best practice to collect reciprocal data (a companion data set where current and potential electrodes are reversed) to gain an informed estimate of the errors associated with ERI measurements (Slater et al., 2000), since underestimating these errors can produce image artifacts in the final ERI result which can mistakenly be interpreted as real structures. In lieu of reciprocal data, we employed a $2 \%$ error model as input to R2 given the low electrical noise expected in our remote field sites and stacking errors (recorded on the instrument) of less than $1.1 \%$.

\subsection{Coring and C storage estimation}

A total of nine core samples were obtained along the linear transects established for geophysical surveys using an Eijkelkamp Russian-style peat auger inserted vertically into the peat layer. Representative $5 \mathrm{~cm}$ peat soil subsamples were taken at $0-30,30-50$ and $50-100 \mathrm{~cm}$ depth intervals and each subsequent $100 \mathrm{~cm}$ interval until mineral substrate was reached. After extraction of core samples, water tables were directly measured using a measuring tape. The length of the sampling device was $9 \mathrm{~m}$, so detection of any deeper boundaries below $9 \mathrm{~m}$ using direct methods was not possible. Peat layers were described in the field as "peat", "transitional" (a mixing horizon of peat and mineral soil) and "mineral soil" (mostly marine-derived fine silt and clay), which represented underlying mineral substrate. The $5 \mathrm{~cm}$ subsamples were oven dried at $60^{\circ} \mathrm{C}$ until constant weight was achieved, 
and weighed for bulk density determination. Peat samples were then sent to the USFS Northern Research Station soil analysis laboratory for carbon analysis. Samples were finely ground, homogenized and analyzed for total C using a LECO TruSpec elemental CN analyzer (LECO Corp, St. Joseph, Michigan). Laboratory standards and analytical duplicates were run every 10 samples to ensure data quality. Peat carbon storage was calculated as

$\mathrm{C}_{\text {peat }}=V \times \mathrm{C}_{\mathrm{d}}$

where $\mathrm{C}_{\text {peat }}$ is carbon storage $\left(\mathrm{MgC} \mathrm{ha}^{-1}\right) ; \mathrm{V}$ is peat volume $\left(\mathrm{m}^{3}\right)$, the product of area (ha) and depth $(\mathrm{cm})$; and $\mathrm{C}_{\mathrm{d}}$ is peat carbon density $\left(\mathrm{kg} \mathrm{C} \mathrm{m}^{-3}\right)$, the product of peat bulk density $\left(\mathrm{kg} \mathrm{m}^{-3}\right)$ and carbon content $(\% \mathrm{C})$.

\subsection{Geophysical surveys}

A set of geophysical surveys combined with direct sampling at each study site consisted of (1) one or more GPR commonoffset transects between 30 and $100 \mathrm{~m}$ long to identify the peat-mineral soil reflector and other stratigraphic features (such as presence of layers rich in woody debris or buried buttressed trees) within the peat soil reflection record; (2) one or more GPR common mid-point surveys to estimate EM wave velocity along the peat column and convert twoway travel time into depth for common-offset profiles; (3) one or more electrical resistivity transects between 48 and $144 \mathrm{~m}$ long to provide additional information related to (a) peat thickness in regions where GPR was anticipated to fail due to thicknesses being greater than the GPR penetration depth and/or excessive GPR attenuation associated with high electrical conductivity and (b) variations in the lithology of the sub-peat mineral deposits; and (4) one or more direct soil cores in order to confirm depth of the peat-mineral soil interface and to obtain samples for subsequent $\mathrm{C}$ analysis at selected locations. Since not every core collected was analyzed for $\mathrm{C}$ content, Table 2 presents a summary of cores collected including average $\mathrm{C}$ percent and content along the peat column.

\section{Results}

\subsection{Tanjung Gunung: shallow peat $(0-4 \mathrm{~m})$}

A set of two orthogonal common-offset profiles were collected at Site TG1 at the $0 \mathrm{~m}$ distance in Line 1 (Fig. 2a) crossing Line 2 (Fig. 2b) at $24 \mathrm{~m}$ along the profile. An average EM wave velocity of $0.04 \mathrm{mns}^{-1}$ for the peat column was estimated from GPR common mid-point profiles (not shown here for brevity). Using this velocity estimate, GPR common-offset profiles (Fig. 2) identified a $4 \mathrm{~m}$ thick peat column that is laterally continuous over the profile.

Direct coring at two locations (shown in Fig. 2a and b) confirms a total peat thickness of $4 \mathrm{~m}$ with a $0.1-0.2 \mathrm{~m}$ sandy clay transition (also containing some organics) into a clayey mineral soil at about $4.2 \mathrm{~m}$ depth. Direct coring also detected the presence of (1) a water table at $0.5 \mathrm{~m}$ depth coinciding with the presence of a distinctive reflector in the GPR record (particularly clear in Fig. 2b); (2) a woody area between 2 and $3 \mathrm{~m}$ depth (indicated in Fig. 2) resulting in isolated points of core refusal that coincide with the presence of hyperbolic diffractions in the reflection record. Extracted core samples showed an average of $58.5 \% \mathrm{C}$ and $\mathrm{C}$ content of 2311.0 $\mathrm{Mg} \mathrm{ha}^{-1}$ (Table 2).

Electrical resistivity imaging results for Line 1 and Line 2 at Site TG1 are shown in Fig. 3a and b, respectively. Direct cores as shown in Fig. 2 are superimposed for comparison. The resistivity inversion shows a relatively conductive (resistivity less than $100 \mathrm{ohm} \mathrm{m}$ ) upper layer, underlain by a more resistive unit of undetermined thickness. The upper layer (showing a progressive increase in resistivity with depth between 60 and $200 \mathrm{ohm} \mathrm{m}$ ) correlates with the terrestrial peat deposit as confirmed from direct sampling and GPR. The underlying resistive layer (ranging between 200 and $300 \mathrm{ohm} \mathrm{m}$ ) includes both a transition layer composed of a mixture of sand and clay (with some organics) and a clayey mineral soil as confirmed from coring. Although lower resistivities are typical for clayey mineral sediments that are usually found below peat, in this case the higher resistivities are attributed to a sandy mineral soil matrix as confirmed from coring in the transition layer.

GPR common-offset profiles at Site TG2 (Figs. 4 and 5) identified a variable peat column ranging between 0.1 and $3.4 \mathrm{~m}$ along the profiles. An average EM wave velocity of $0.038 \mathrm{~m} \mathrm{~ns}^{-1}$ for the peat column (slightly lower than that at TG1) was estimated from GPR common mid-point profiles. As shown in the reflection record in Fig. 4a and confirmed with direct coring, the reflector interpreted as the peat-mineral soil interface deepens from the surface (at $70 \mathrm{~m}$ along the profile where the reflector is not discernible from the ground coupling) to $1.5 \mathrm{~m}$ (at $74 \mathrm{~m}$ along the profile) towards the NE, representing a total increase of $1.4 \mathrm{~m}$ in peat thickness over a $4 \mathrm{~m}$ horizontal distance (i.e., between 70 and $74 \mathrm{~m}$ along the profile). This trend extends to the end of the profile where the peat-mineral soil exceeds depths of $3 \mathrm{~m}$, where peat thickness increases by over $3 \mathrm{~m}$ in about $20 \mathrm{~m}$ along the transect. The ERI images are consistent with this interpretation (Fig. 4b) depicting a resistive upper layer (100-370 ohm m interpreted as peat) underlain by a conductive unit (as low as $20 \mathrm{ohm} \mathrm{m}$ ) interpreted as clay and confirmed from both coring and surface outcrops between 0 and $60 \mathrm{~m}$ along the transect. Figure 5a represents the continuation of the GPR common-offset profile in Fig. 4a towards the NE. In this case peat thickness is almost uniform (as confirmed with coring and depicted in Fig. 5a), with peat thickness changing only by $0.4 \mathrm{~m}$ across the $100 \mathrm{~m}$ long profile. This profile also confirms the presence of a distinctive reflector at about $0.8 \mathrm{~m}$ depth interpreted as the water table as confirmed from coring. Although the coring did not explic- 
Table 2. Summary of cores including coordinates, landcover, peat depth (from direct coring), $\mathrm{C}$ stock along the peat profile (in $\mathrm{Mg}^{-1}$ ) and mean $\% \mathrm{C}$ in the peat layer.

\begin{tabular}{|c|c|c|c|c|c|c|}
\hline Core & $\begin{array}{l}\text { Coordinates } \\
\text { (deg) }\end{array}$ & Landcover & $\begin{array}{r}\text { Peat depth } \\
(\mathrm{m})\end{array}$ & $\begin{array}{r}\text { Peat profile } \\
\text { C stock } \\
\left(\mathrm{Mg} \mathrm{ha}^{-1}\right)\end{array}$ & $\begin{array}{r}\text { Mean peat } \\
\text { bulk density } \\
\left(\mathrm{g} \mathrm{cm}^{-3}\right)\end{array}$ & $\begin{array}{r}\text { Mean peat } \mathrm{C} \\
(\% \mathrm{C})\end{array}$ \\
\hline TG1.1 & $\begin{array}{l}\text { Lat: } 110.0699 \\
\text { Long: }-1.3036\end{array}$ & Thinned forest & 4.1 & 2300.53 & 0.10 & 57.74 \\
\hline TG1.2 & $\begin{array}{l}\text { Lat: } 110.0702 \\
\text { Long: }-1.3035\end{array}$ & Thinned forest & 4.1 & 2321.39 & 0.10 & 59.33 \\
\hline TG2.1 & $\begin{array}{l}\text { Lat: } 110.0631 \\
\text { Long: }-1.2986\end{array}$ & Rubber plantation & 3.0 & 1662.02 & 0.11 & 52.13 \\
\hline TG2.2 & $\begin{array}{l}\text { Lat: } 110.0633 \\
\text { Long: }-1.2989\end{array}$ & Rubber plantation & 3.0 & 1764.31 & 0.16 & 41.60 \\
\hline TG2.3 & $\begin{array}{l}\text { Lat: } 110.0637 \\
\text { Long: }-1.2981\end{array}$ & Rubber plantation & 3.4 & 1623.72 & 0.09 & 54.20 \\
\hline P1.1 & $\begin{array}{l}\text { Lat: } 110.1524 \\
\text { Long: }-1.8644\end{array}$ & Disturbed forest & 5.0 & 3039.36 & 0.13 & 49.10 \\
\hline P1.2 & $\begin{array}{l}\text { Lat: } 110.1521 \\
\text { Long: }-1.8641\end{array}$ & Disturbed forest & 4.3 & 2314.92 & 0.12 & 52.46 \\
\hline P2.1 & $\begin{array}{l}\text { Lat: } 110.1272 \\
\text { Long: }-1.8999\end{array}$ & Thinned forest & $>9.0$ & 5676.67 & 0.11 & 57.82 \\
\hline $\mathrm{P} 2.2$ & $\begin{array}{l}\text { Lat: } 110.1277 \\
\text { Long: }-1.8997\end{array}$ & Thinned forest & 8.3 & 6107.92 & 0.13 & 56.12 \\
\hline
\end{tabular}

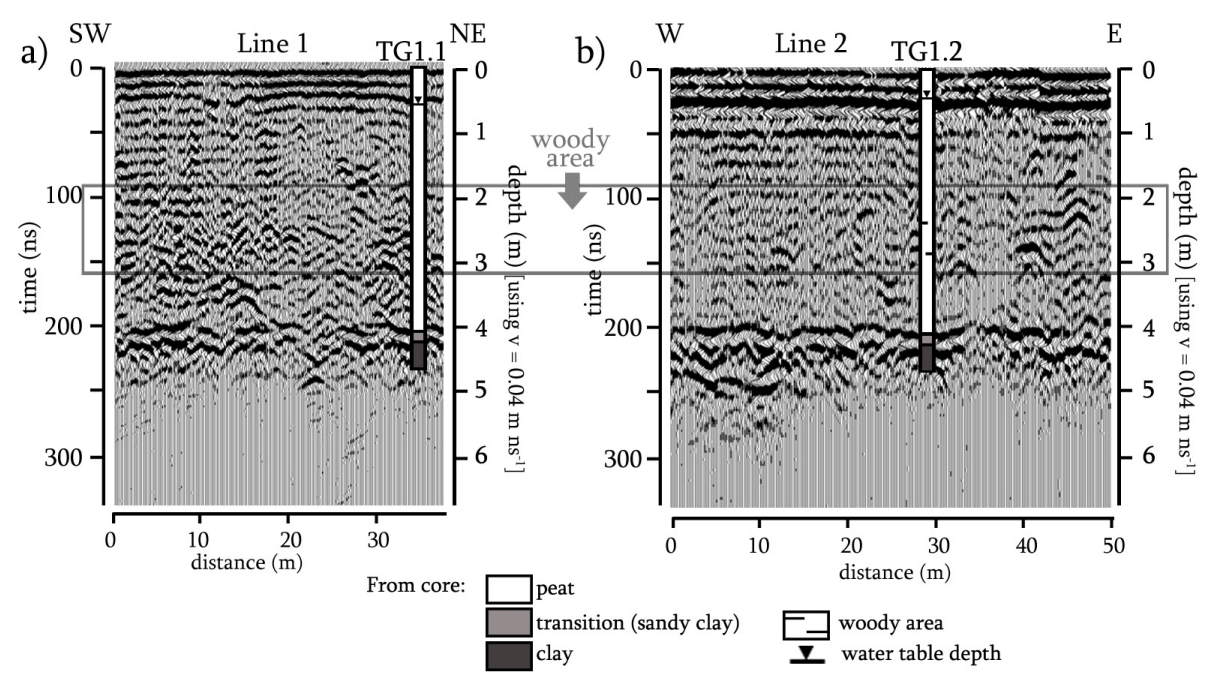

Figure 2. GPR common-offset profile using a MALÅ GPR system with $100 \mathrm{MHz}$ antennae along Line 1 (a) and Line 2 (b). Location of core samples TG1.1 and TG1.2 and inferred units, water table position and presence of wood layers are also shown. Frame highlights the location of a woody area identified along the cores and characterized by the presence of hyperbolic diffractions in the GPR record.

itly detect points of core refusal (like those at TG1), the GPR record also shows the presence of hyperbolic diffractions in the reflection record (i.e., between 40 and $85 \mathrm{~m}$ along the transect and between 2 and $3 \mathrm{~m}$ depth in Fig. 5a as indicated by white arrows). The ERI image in Fig. 5 b follows the GPR profile in Fig. 5a and is consistent with the results shown in Fig. $4 \mathrm{~b}$ depicting a resistive upper layer $(100-370 \mathrm{ohm} \mathrm{m}$ interpreted as peat) underlain by a conductive unit (as low as $20 \mathrm{ohm} \mathrm{m}$ ) interpreted as clay. For TG1.1-TG1.3, the organic soil had an average $\mathrm{C}$ percent of $49.3 \% \mathrm{C}$ and $\mathrm{C}$ content of 1683.4 $\mathrm{Mg} \mathrm{ha}^{-1}$ (Table 2).

\subsection{Pelang forest: intermediate and deep peat (5-9 m)}

Geophysical surveys constrained with direct coring at Pelang forest contrast with those previously described at Tanjung Gunung with greater peat thicknesses, ranging between $5 \mathrm{~m}$ at Site P1 up to $9 \mathrm{~m}$ at Site P2. GPR and electrical resistivity 

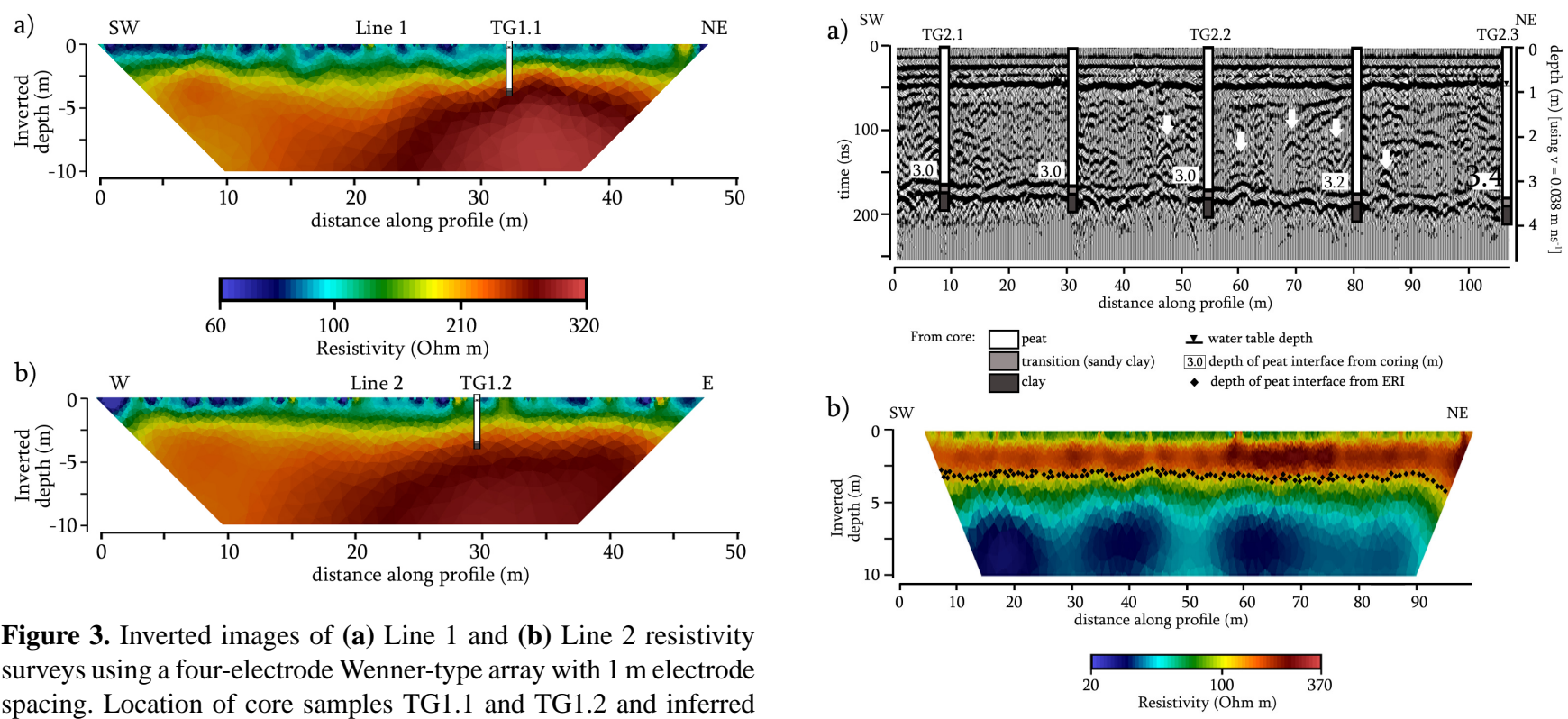

Figure 3. Inverted images of (a) Line 1 and (b) Line 2 resistivity surveys using a four-electrode Wenner-type array with $1 \mathrm{~m}$ electrode spacing. Location of core samples TG1.1 and TG1.2 and inferred units as per Fig. 2 are also shown.
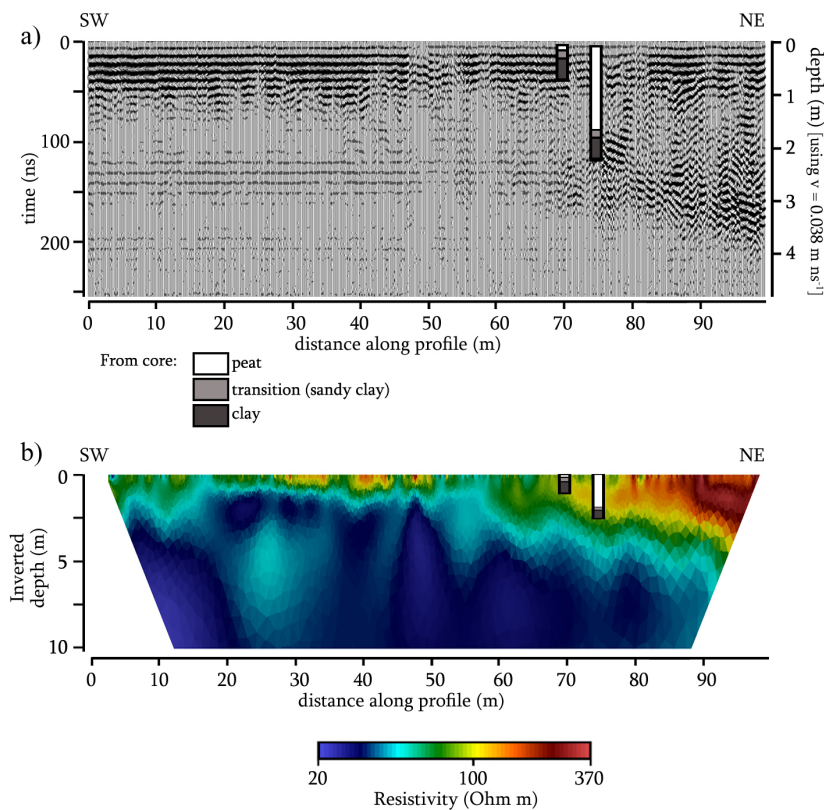

Figure 4. (a) GPR common-offset profile using a MALA GPR system with $200 \mathrm{MHz}$ antennae at Site TG2. Location of two core samples and inferred units are also shown; (b) inverted image of resistivity survey along the GPR profile in (a) using a four-electrode Wenner-type array with $1 \mathrm{~m}$ electrode spacing.

surveys at Site P1 were collected at different locations separated by about $1 \mathrm{~km}$ since GPR transects at this site were not accessible with heavy resistivity instrumentation. Similar to Site TG1, an average EM wave velocity of $0.04 \mathrm{~m} \mathrm{~ns}^{-1}$ for the peat column was estimated from GPR common midpoint profiles at this site. GPR common-offset profiles at Site P1 (Fig. 6) show a reflection record characterized by: (1) a 


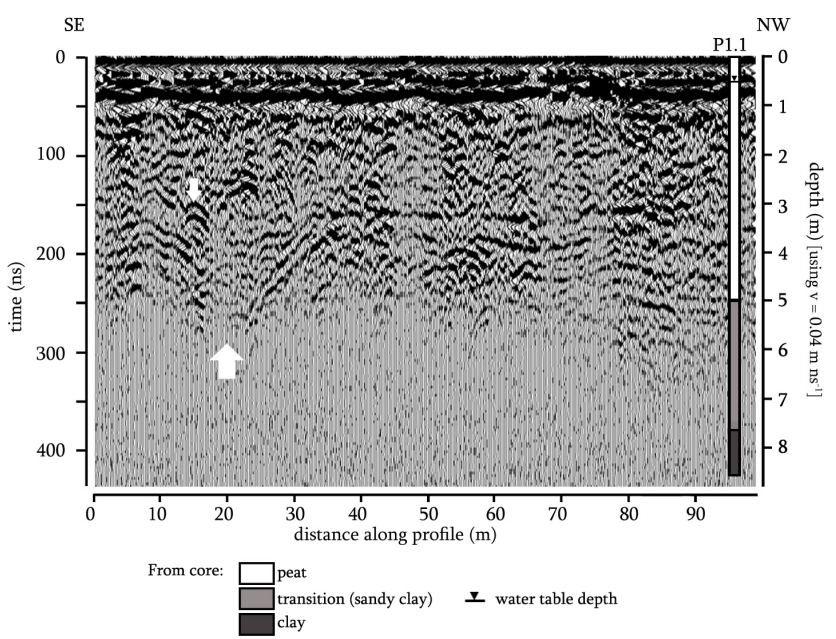

Figure 6. GPR common-offset profile using a MALÅ GPR system with $100 \mathrm{MHz}$ antennae at Site P1. Location of core sample P1.1 and inferred units and water table position are also shown. Larger white arrow indicates the center of a depressional feature within the reflection record centered between 10 and $35 \mathrm{~m}$ along the profile and 3-5 $\mathrm{m}$ depth. Smaller white arrow indicates the presence of a diffraction hyperbola.

thickness of about $2.5 \mathrm{~m}$ identified in the coring. Although not directly confirmed from coring, it appears the interface between the peat and the sandy clay is variable across the profile in Fig. 7, indicating undulating peat thickness between $5 \mathrm{~m}$ (i.e., at core location at $22 \mathrm{~m}$ along the line, and at 70,105 or $120 \mathrm{~m}$ along the line based on ERI alone) and $7.5-8 \mathrm{~m}$ (i.e., at 12,90 or $130 \mathrm{~m}$ along the profile). The ERI profile also shows a strong lateral resistivity variation in the deeper mineral soil (i.e., below $10 \mathrm{~m}$ depth) varying between 30 and $100 \mathrm{ohm} \mathrm{m}$ from the SE to the NW. Cores P1.1 and $\mathrm{P} 1.2$ averaged $50.8 \% \mathrm{C}$ with a $\mathrm{C}$ content of $2677.1 \mathrm{Mg} \mathrm{ha}^{-1}$ (Table 2).

Variability in peat thickness at Site P2 (Fig. 8) is similar to that described for Site P1 (Fig. 7) and is confirmed at three coring locations (at 10, 50 and $100 \mathrm{~m}$ along the profile) resulting in total peat thicknesses of $9 \mathrm{~m}$ or more, 8.7 and $8.8 \mathrm{~m}$, respectively. Since topography can be considered flat at the scale of measurement used in this profile, these results confirm that the interface between the peat and the underlying sandy clay transition is undulating and that resistivity values for the peat (between 100 and $185 \mathrm{ohm} \mathrm{m}$ ) and transitional layer (below $100 \mathrm{ohm} \mathrm{m}$ ) are consistent with those shown in Fig. 7. The clay layer imaged with the resistivity profile in Fig. 7 (and confirmed from coring in that figure) is also visible in Fig. 8 just below the transitional layer and at approximate depths between 10 and $14 \mathrm{~m}$. For cores P2.1 and P2.2 the soils averaged $57.0 \% \mathrm{C}$ with a $\mathrm{C}$ content of $5892.3 \mathrm{Mg} \mathrm{ha}^{-1}$ (Table 2).

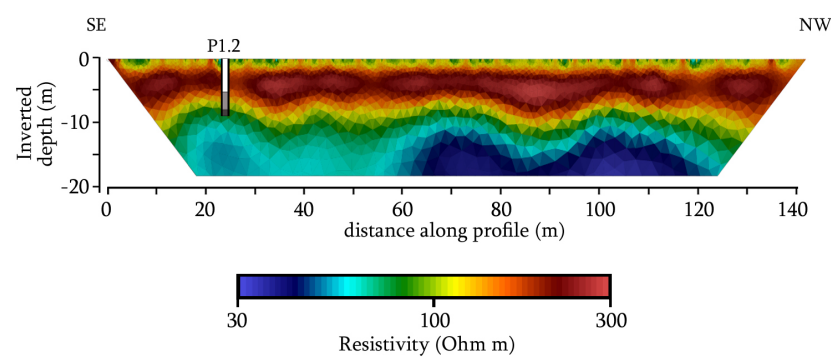

Figure 7. Inverted image of resistivity survey at Site P1 using a four-electrode Wenner-type array with $2 \mathrm{~m}$ electrode spacing. Note that the resistivity profile does not coincide with the location of GPR profile shown in Fig. 6. Location of core sample P1.2 and inferred units (depicted in Fig. 6) are also shown.

\section{Discussion}

\subsection{Peat thickness}

In general, peat thickness estimates using GPR and ERI were consistent across sites although several differences between methodologies are noted. GPR was particularly effective for characterizing peat thickness for shallow peat columns (i.e., TG1 and TG2 in Figs. 2 and 5b, respectively) and able to quantify depth of the peat-mineral soil interface at centimeter-scale resolution both vertically and laterally from a strong reflector that matched closely with coring results. This reflector resembles the peat-mineral soil interface as typically detected with GPR in boreal peatlands in North America and Europe, exemplified in several studies for those higher-latitude systems (Warner et al., 1990; Jol and Smith, 1995; Slater and Reeve, 2002; Parsekian et al., 2012; Comas et al., 2013). However, the GPR method, as used with antenna frequencies available for this study, was limited for imaging deep (i.e., $9 \mathrm{~m}$ or more) peat columns (i.e., Sites P1 and P2) in this study. We attribute these limitations to (1) thicker peat columns that excessively attenuate the GPR signal, and/or (2) attenuation due to the presence of clay-rich transition layers with high electrical conductivities as depicted by the low resistivity values in P1 and P2 (Figs. 7 and 8). Attenuation in clay-rich areas was to be expected since it is well known than the effectiveness of GPR in peatlands is compromised when electrical conductivity of peat is high due to high electrical fluid conduction or high percent of clay fractions (Theimer et al., 1994).

Electrical resistivity imaging also proves useful for detecting changes in peat thickness across sites and for estimating the depth of interface between peat and mineral soil. When compared to GPR, electrical resistivity shows similar imaging capabilities for estimating both shallow and deep peat columns in the study areas (due to larger depths of investigation), although resolution (both vertical and lateral) is lower than that of GPR, particularly as depth increases. The boundaries between the upper resistive layer corresponding to the 


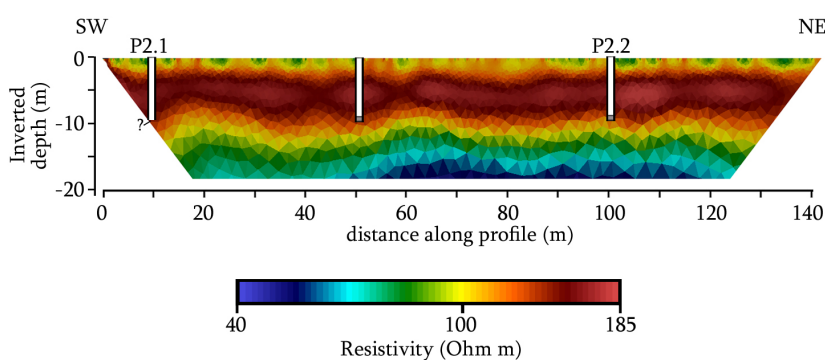

Figure 8. Inverted image of resistivity survey at Site P2 using a four-electrode Wenner-type array with $2 \mathrm{~m}$ electrode spacing. Location of core sample P2.1, P2.2 and one additional location and inferred units (depicted in Fig. 6) are also shown.

peat and the underlying conductive materials corresponding to the clay and transitional layer are not clear and are depicted by a gradual increase in conductivity (see Figs. 4b, 7, and 8). These results are consistent with previous studies in northern peatlands which demonstrate that electrical conductivity is not an accurate indicator of peat thickness when peat is underlain by a conductive layer (Slater and Reeve, 2002). The results presented here also confirm the same issue when peat is underlain by a resistive material (Fig. 3), which is not uncommon in Indonesia. For example, sandy mineral soils below the organic sediments of other peatlands in Central Kalimantan have been reported (Shimada et al., 2001). Despite these limitations, a good correspondence exists between the limit of the uppermost high resistivity values at sites TG2, P1 and P2 (depicted in red and orange in Figs 4b, 7, and 8) and the peat layer interface.

Although GPR and ERI data sets presented here are limited in terms of areal extent and scale of measurement, our intent was to test and demonstrate the potential of the methods for estimating peat thickness in tropical peatlands at better resolution than traditional methods (i.e., coring). Therefore, geophysical surveys were developed at plot-level scales with average profiles of $100 \mathrm{~m}$, with the aim of upscaling measurements in subsequent studies. Furthermore, the ultimate aim of this work is to increase the accuracy of peat $\mathrm{C}$ storage estimates by using methods able to quantify peat thickness at high lateral resolution (i.e., reaching $\mathrm{cm}$ for GPR) when compared to coring. It is important to consider that GPR or ERI as applied here detects interfaces representing contrasts in physical properties which can be used to obtain highly accurate estimates of peat volume. When combined with sampling of representative peat soils for $\mathrm{C}$ density determination, total peat carbon storage estimates can be undertaken largely at the site level.

\subsection{Peat C stocks}

The profile from Site TG-2 in Fig. 5 can be used to investigate how subtle changes in peat thickness as detected from GPR (representing a maximum gradient below $0.02^{\circ}$ )

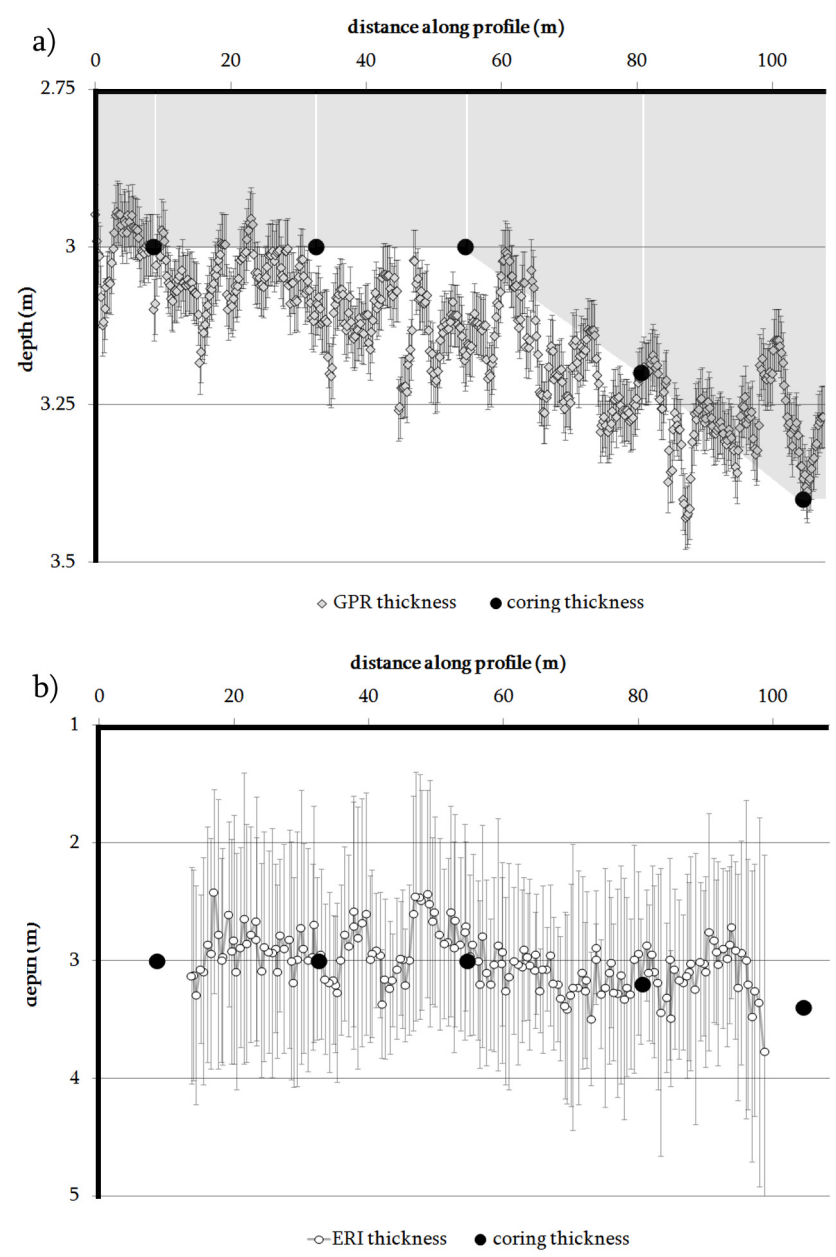

Figure 9. Comparison of peat thickness estimated from the (a) GPR profile and (b) the ERI image as shown in Fig. 5 (based on an average velocity of $0.038 \mathrm{~m} \mathrm{~ns}^{-1}$ ) and direct coring at five locations. Error bars in the data were calculated from the difference in peat thickness between GPR using that average velocity and ERI and that measured from the coring. Grey shading indicates estimated surface area from coring.

may influence overall peat carbon stock estimates. Figure 9 shows a comparison between (a) peat thickness estimated from GPR at a total of 539 locations (or every $0.2 \mathrm{~m}$ along the profile shown in Fig. 5a) and direct coring at five locations (or approximately every $20 \mathrm{~m}$ along the profile as show in Fig. 9a and b) peat thickness estimated from ERI at a total of 190 locations (interface shown in Fig. 5b) and direct coring at five locations (Fig. 9b). GPR estimates in Fig. 9a are based on an average velocity of $0.038 \mathrm{~m} \mathrm{~ns}^{-1}$ for the entire peat column as determined from common midpoint surveys at two different locations at TG2 using two different antenna frequencies (i.e., 100 and $200 \mathrm{MHz}$ ), and the travel time recorded at the five coring locations (consistently showing estimates $0.038 \pm 0.001 \mathrm{~m} \mathrm{~ns}^{-1}$ ). The lower peat boundary was selected from the ERI image using the average in- 
verted resistivity value at pixels corresponding to the interface identified from coring (mean of $131 \mathrm{ohm} \mathrm{m}$, standard deviation of $17 \mathrm{ohm} \mathrm{m}$ ). Lateral variability in depth to mineral soil at TG2 ranges between 2.9 and 3.4 from the GPR and 2.4-3.7 $\mathrm{m}$ as estimated from the ERI images (Fig 9a and b, respectively), confirming that substrate topography is highly variable laterally. These results also confirm previous studies showing lateral variability in mineral substrate topography across several peat domes in Borneo (Dommain et al., 2010 after Konsultant, 1998). Furthermore, these results confirm that vertical resolution of peat profiles obtained from ERI is lower than those obtained using GPR, as expected.

Error bars in the GPR data $( \pm 0.05 \mathrm{~m}$ average in Fig. 9a) were calculated from the difference in peat thickness between GPR using the average velocity of $0.038 \mathrm{~m} \mathrm{~ns}^{-1}$ and that measured from the coring. Error bars in the ERI data (Fig. 9b) were computed as the maximum misfit at each horizontal location between (1) the interpolated interface depth taken from coring and (2) the ERI estimated interface depth using the mean resistivity value \pm 2 standard deviations. Assuming that lateral variability in peat thickness between cores is non-existent when the same thickness is estimated for contiguous cores (i.e., perfectly horizontal interface), and that thickness increases gradually with distance (i.e., constant gradient) as shown in the shaded areas in Fig. 9a, the overall peat surface area for the profile is estimated to be $324 \mathrm{~m}^{2}$. Thickness estimated from individual GPR traces (every $0.2 \mathrm{~m}$ ), produces an overall peat surface area of $331 \mathrm{~m}^{2}$, an increase of $2.1 \%$. The difference in surface area represents a total increase of $1171 \mathrm{~kg}$ of $\mathrm{C}$ along the two dimensional profile if we assume a $\mathrm{C}$ content of $1673.1 \mathrm{Mg} \mathrm{Cha}^{-1}$ as averaged for the peat column in Core TG2.1-TG2.3 (Table 2). Due to the limitations in terms of (a) vertical resolution, and (b) lateral extent of the profile (i.e., low image resolution on the edges of the profiles), a similar approach using ERI peat thickness estimates is more uncertain and therefore is not included here. Variability in peat thickness was only $2.9-3.4 \mathrm{~m}$ (estimated from GPR traces) or $0.4-0.5 \mathrm{~m}$ over the $100 \mathrm{~m}$ TG2 transect. Although the $7 \mathrm{~m}^{2}$ difference in surface area between GPR and coring measurements represents only $0.07 \mathrm{~m}$ in average peat thickness, when scaled per area the difference between GPR and coring estimates is $37 \mathrm{MgC} \mathrm{ha}^{-1}$, which illustrates how relatively small differences in depth estimates can impact overall C storage calculations. Since most peat formations in Indonesia occur at much larger spatial scales (i.e., tens of kilometers or more), GPR surveys over broader areas are shown here to be capable of largely reducing uncertainties regarding peat thickness and $\mathrm{C}$ storage. Moreover, as peat $\mathrm{C}$ density in tropical peat soils becomes better constrained (Rodríguez et al., 2013), local to regional estimates of peat $\mathrm{C}$ storage can be improved through the use of GPR methods to accurately determine peat thickness. Considering that peat thickness can also change dramatically over short distances depending on geomorphic setting (e.g., about $1.5 \mathrm{~m}$ difference in peat thickness within only $4 \mathrm{~m}$ along the Site TG-2 profile in Fig. 4), measuring peat thickness at finer spatial resolution would thus significantly improve current $\mathrm{C}$ stock estimates.

\subsection{Peat formation}

The results presented here also demonstrate potential for using GPR and ERI methods to improve the understanding of processes associated with peatland formation. Differences in the GPR reflection record and contrasts in electrical conductivity between the two study sites (TG and P) are interpreted as differences in peat ecosystem type and developmental history between sites. First, there is a sharp difference between the profiles at TG1 and TG2, as the resistivity profile increases with depth at TG1 (i.e., higher resistivity at the bottom of the profile, Fig. 3), whereas it decreases at TG2 (i.e., lower resistivity at the bottom of the profile, Fig. 3). Second, the interface between peat and mineral soil at TG1 and TG2 is characterized by a set of 2-3 sharp reflectors in the GPR record (see Figs. 2, 4 and 5), which are absent at Site $\mathrm{P}$ where reflectors are sharply attenuated when reaching depths corresponding to the transition zone between peat and clay. Third, resistivity results do not show marked differences in terms of electrical conductivity between sites along the peat-clay interface, although coring results show a marked increase in thickness of the transition zone (mostly corresponding to mixtures of clay and sand) with averages between 0.1 and $0.2 \mathrm{~m}$ for Sites TG1 and TG2 and averages reaching $2.5 \mathrm{~m}$ for Site P1. These differences may be attributed to two related issues: (1) the developmental history of peatland initiation and formation at each specific site and (2) the differences in site location as related to physiographic type of terrain and the characteristics of peat ecosystems at each site. As shown in Fig. 1, sites TG1 and TG2 correspond to MDW or shallow peat swamp ecosystems, while sites P1 and P2 are characterized by GBT or large ombrotrophic peat swamp ecosystems. Coastal peat swamps in Kalimantan have been described as being the result of peat accumulation developed on marine clay and mangrove deposits of river deltas and coastal plains during the mid- to late Holocene ( $\sim 5000$ cal BP) (Supiandi, 1988; Dommain et al., 2011). As sea levels fell around $5000 \mathrm{cal}$ BP, sandy beach ridges were exposed and developed into peat swamps, and mud flats were covered by mangroves (Cameron et al., 1989; Dommain et al., 2011, 2014). While sites at TG may be related to peat swamp colonization over sandy ridges (as reflected by the presence of a highly resistive mineral soil at TG1 and/or a thin transitional layer at both TG1 and TG2), sites at P may be characterized by colonization of mud flats and mangrove deposits (as characterized by much thicker organomineral mixing horizons and potential increased electrical conductivity that results in a marked attenuation in the GPR reflection record, see Fig. 6). Furthermore, the ERI profiles also show lateral variation in resistivity associated with variability in the topography of the deeper mineral soil and 
associated with peat thickness (see Figs. 5b and 9b). Local depressions can be also identified in Fig. 7 (i.e., around 80$100 \mathrm{~m}$ distance along the profile) and suggest that peat soil undulates at a fine scale. Similar features can also found in Fig. 8 (i.e., between 20 and $50 \mathrm{~m}$ distance along the profile).

\subsection{Peat matrix}

Finally, the spatial resolution provided by GPR commonoffset profiles also shows the potential for better understanding the nature and internal structure of the peat matrix. For example, referring to the presence of hyperbolic diffractions in the GPR record, Figs. 2a, b and 5 show the presence of several areas with a high density of diffractions. These diffractions are particularly abundant in Fig. 2a between 10 and $20 \mathrm{~m}$ distance along the profile and at $2.5-3 \mathrm{~m}$ depth, or in Fig. 5 between 70 and $85 \mathrm{~m}$ distance along the profile and between 2 and $3 \mathrm{~m}$ depth (white arrows in Fig. 5). Diffractions are associated with the presence of objects that may act as isolated reflector points such as cobbles and boulders (Neal, 2004). In this case, we associate hyperbolic diffractions in GPR common offsets with the presence of buried woody debris (as further confirmed through coring). Other investigations in northern peatlands have also related GPR diffractions to the presence of wood (Slater and Reeve, 2002; Comas et al., 2008). Such features are absent at P1 (Fig. 6), where more laterally continuous reflections (i.e., at 3, 4 and $4.5 \mathrm{~m}$ depth between 40 and $90 \mathrm{~m}$ along the profile) are present. Previous studies in the Kalimantan region have also consistently shown layers with large quantities of undecomposed woody fragments heterogeneously distributed within the peat column (Shimada et al., 2001). Furthermore, some of these laterally continuous reflectors generate a depressional feature between 10 and $30 \mathrm{~m}$ along the profile of $\mathrm{P} 1$ (center point indicated by a white arrow in Fig. 6) as depicted by a sharp reflector at depths between 3.5 and almost $6 \mathrm{~m}$ that tilts 13 and $9^{\circ}$ respectively on the NW and SE sides of the profile. Although not directly confirmed in the field through direct coring, this feature might be related to the presence of buttressed trees which often prompt the formation of hummocks and water ponding upslope (Dommain et al., 2010), or the uprooting of such trees due to wind and the formation of depressional features as the root zone is displaced. Alternatively, these feature may also be associated with the infill process in a tip-up pool. As described by Dommain et al. (2015) for peatlands in Borneo, tip-up pools are commonly formed when lightning strikes a tree inducing its fall and generating a discontinuity in the peat deposit and a pool subsequently infilled with younger material. The horizonal reflectors seem to overlap the tilting reflectors, suggesting that the depression may have formed suddenly, to be later filled up progressively with younger peat. Although this may represent an isolated feature in our data set, Dommain et al. (2015) have recently demonstrated the importance of such features when describ- ing carbon accumulation rates and how it may complicate paleoenvironmental reconstructions.

\section{Conclusions}

This study demonstrates the feasibility of using GPR and ERI for non-invasive mapping of the subsurface of peatlands in Indonesia, at a spatial resolution previously unreported in tropical peatland systems, which are traditionally assessed using coring methods. The results presented highlight the opportunity to use the reflection record from GPR to improve peat thickness estimates while providing information on certain attributes of the peat matrix such as presence of wood layers, buttressed trees or tip-up pools or peat soil origins related to peatland ecosystem type (i.e., mangrove vs. freshwater peat). While in general GPR is able to predict peat thickness with centimeter resolution some limitations emerged (i.e., signal attenuation) for peat columns exceeding $5 \mathrm{~m}$ thick. Although the vertical resolution of ERI is more limited, peat thickness determination shows comparable results for either shallow or deep peat columns. A comparison between peat thickness estimates from GPR, ERI and coring showed a variability exceeding $2 \%$ in peat surface area (or $1191 \mathrm{~kg}$ of $\mathrm{C}$ assuming $\mathrm{C}$ contents of $170 \mathrm{~kg} \mathrm{C} \mathrm{m}^{-2}$ as averaged from core samples), although this was based on a short $100 \mathrm{~m}$ two dimensional profile indicating changes in thickness of less than $0.5 \mathrm{~m}$. Such discrepancies may be larger when considering transects with a more variable peat thickness (such as those here showing up to $1.5 \mathrm{~m}$ vertical difference over only $4 \mathrm{~m}$ in the horizontal). Given the difficulty of capturing such variability with traditional methods (such as coring), estimating total $\mathrm{C}$ stocks in Indonesian peatlands at local scales should be revisited using methods such as GPR or electrical resistivity imaging that better account for lateral variability.

Acknowledgements. This work was supported by the US Agency for International Development (USAID). We are indebted to Kent Elliot (US Forest Service) for all his help with logistics and fieldwork during this study. We are also thankful to Sofyan Kurnianto (CIFOR, Oregon State University) and Ophelia Wang (USAID-IFACS) for their help in the field, and to all local field assistants and guides involved in this research for their support at the study sites. We thank R. Dommain for helpful discussions and revisions in the materials presented in this study. We also thank four anonymous reviewers and the editor for helpful comments which improved an earlier version of this manuscript.

Edited by: A. Ito

\section{References}

Binley, A. and Kemna, A.: DC Resistivity and Induced Polarization Methods. In: Hydrogeophysics, edited by: Rubin, Y. and Hub- 
bard, S. S., Water Science and Technology Library, Springer, New York, 2005.

Cameron, C. C., Esterle, J. S., and Curtis, A. P.: The geology, botany and chemistry of selected peat-forming environments from temperate and tropical latitudes, Int. J. Coal Geol., 12, 105-156, 1989.

Comas, X. and Slater, L.: Evolution of biogenic gasses in peat blocks inferred from non-invasive dielectric permittivity measurements, Water Resour. Res., 43, W05424, doi:10.1029/2006WR005562, 2007.

Comas, X. and Slater, L.: Non-Invasive Field-Scale Characterization of Gaseous-Phase Methane Dynamics in Peatlands Using the Ground Penetrating Radar (GPR) Method, in: Carbon Cycling in Northern Peatlands, edited by: Baird, A., Belyea, L., Comas, X., Reeve, A., and Slater, L., American Geophysical Union (AGU), 2009.

Comas, X., Slater, L., and Reeve, A.: Geophysical evidence for peat basin morphology and stratigraphic controls on vegetation observed in a Northern Peatland, J. Hydrol., 295, 173-184, 2004.

Comas, X., Slater, L., and Reeve, A.: Seasonal geophysical monitoring of biogenic gases in a northern peatland: implications for temporal and spatial variability in free phase gas production rates, J. Geophys. Res., 113, G01012, doi:01010.01029/02007JG000575, 2008

Comas, X., Slater, L., and Reeve, A. S.: Pool patterning in a northern peatland: Geophysical evidence for the role of postglacial landforms, J. Hydrol., 399, 173-184, 2011.

Comas, X., Kettridge, N., Binley, A., Slater, L., Parsekian, A., Baird, A. J., Strack, M., and Waddington, J. M.: The effect of peat structure on the spatial distribution of biogenic gases within bogs, Hydrol. Process., 28, 5483-5494, doi:10.1002/hyp.10056, 2013.

Dommain, R., Couwenberg, J., and Joosten, H.: Hydrological selfregulation of domed peatlands in south-east Asia and consequences for conservation and restoration, Mires Peat, 6, 1-17, 2010.

Dommain, R., Couwenberg, J., and Joosten, H.: Development and carbon sequestration of tropical peat domes in south-east Asia: links to post-glacial sea-level changes and Holocene climate variability, Quat. Sci. Rev., 30, 999-1010, 2011.

Dommain, R., Couwenberg, J., Glaser, P. H., Joosten, H., Nyoman, I., and Suryaputra, N.: Carbon storage and release in Indonesian peatlands since the last deglaciation, Quat. Sci. Rev., 97, 1-32, 2014.

Dommain, R., Cobb, A. R., Joosten, H., Glaser, P. H., Chua, A. F. L., Gandois, L., Kai, F.-M., Noren, A., Salim, K. A., Su'ut, N. S. H., and Harvey, C. F.: Forest dynamics and tip-up pools drive pulses of high carbon accumulation rates in a tropical peat dome in Borneo (Southeast Asia), J. Geophys. Res.-Biogeo., doi:10.1002/2014jg002796, 2015.

Geuzaine, C. and Remacle, J. F.: Gmsh: a three-dimensional finite element mesh generator with built-in pre- and post-processing facilities, Int. J. Numer. Meth. Eng., 79, 1309-1331, 2009.

Hooijer, A., Silvius, M., Woesten, H., and Page, S.: Peat- $\mathrm{CO}_{2}$ : Assessment of $\mathrm{CO}_{2}$ emissions from drained peatlands in SE Asia; Delft Hydraulics report Q3943, 41 pp., 2006.

Jaenicke, J., Rieley, J. O., Mott, C., Kimman, P., and Siegert, F.: Determination of the amount of carbon stored in Indonesian peatlands, Geoderma, 147, 151-158, 2008.
Jol, H. M. and Smith, D. G.: Ground penetrating radar surveys of peatlands for oilfield pipelines in Canada, J. Appl. Geophys., 34, 109-123, 1995.

Joosten, H.: The Global Peatland $\mathrm{C}_{\mathrm{O}} 2$ Picture, Ede, 33 pp., 2009.

Konsultant, P.: Detailed Design and Construction Supervision of Flood Protection and Drainage Facilities for Balingian RGC Agricultural Development Project, Sibu Division, Sarawak (Inception Report), Kuching, 24 pp., 1998.

Menke, W.: Geophysical Data Analysis: Discrete Inverse Theory, Academic Press Inc., New York, 1989.

Meyer, J. H.: Investigation of Holocene organic sediments: a geophysical approach, Int. Peat J., 3, 45-57, 1989.

Neal, A.: Ground-penetrating radar and its use in sedimentology: principles, problems and progress, Earth-Sci. Rev., 66, 261-330, 2004.

Page, S. E., Siegert, F., Rieley, J. O., Boehm, H.-D. V., Jaya, A., and Limin, S.: The amount of carbon released from peat and forest fires in Indonesia during 1997, Nature, 420, 61-65, 2002.

Page, S. E., Rieley, J. O., and Banks, C. J.: Global and regional importance of the tropical peatland carbon pool, Glob. Change Biol., 17, 798-818, 2011.

Parry, L. E., West, L. J., Holden, J., and Chapman, P. J.: Evaluating approaches for estimating peat depth, J. Geophys. Res.-Biogeo., 119, JG002411, doi:10.1002/2013JG002411, 2014.

Parsekian, A. D., Slater, L., Sebestyen, S. D., Kolka, R. K., Ntarlagiannis, D., Nolan, J., and Hanson, P.: Comparison of uncertainty in peat volume and soil carbon estimated using GPR and probing, Soil Sci. Soc. Am. J., 76, 1911-1918, 2012.

RePPProT: Regional Physical Planning Programme for Transmigration, The land resources of Indonesia: a national overview, Main report, Ministry of Transmigration and Land Resources Department/Bina Program., Jakarta, 1990.

Ritung, S., Wahyunto, Nugroho, K., Sukarman, Hikmatullah, Suparto, and Tafakresnanto, C.: Peta Lahan Gambut Indonesia Skala 1:250 000 (Indonesian peatland map at the scale 1:250 000) Bogor, Indonesia, 2011.

Rodríguez, V., Gutiérrez, F., Green, A. G., Carbonel, D., Horstmeyer, H., and Schmelzbach, C.: Characterising saging and collapse sinkholes in a mantled karst by means of Ground Pnentrating Radar (GPR), Environ. Eng. Geosci., 20, 109-132, 2013.

Rosa, E., Larocque, M., Pellerin, S., Gagné, S., and Fournier, B.: Determining the number of manual measurements required to improve peat thickness estimations by ground penetrating radar, Earth Surf. Proc. Land., 34, 377-383, 2009.

Shimada, S., Takahashi, H., Haraguchi, A., and Kaneko, M.: The carbon content characteristics of tropical peats in Central Kalimantan, Indonesia: Estimating their spatial variability in density, Biogeochemistry, 53, 249-267, 2001.

Slater, L. and Reeve, A.: Understanding peatland hydrology and stratigraphy using integrated electrical geophysics, Geophysics, 67, 365-378, 2002.

Slater, L., Binley, A. M., Daily, W., and Johnson, R.: Cross-hole electrical imaging of a controlled saline tracer injection, J. Appl. Geophys., 44, 85-102, 2000.

Supiandi, S.: Studies on peat in the coastal plains of Sumatra and Borneo. Part I: Physiography and geomorphology of the coastal plains, Southeast Asian Studies, 26, 308-335, 1988.

Theimer, B. D., Nobes, D. C., and Warner, B. G.: A study of the geoelectrical properties of peatlands and their influence on ground- 
penetrating radar surveying, Geophysical Prospecting, 42, 179209, 1994.

van der Werf, G. R., Morton, D. C., DeFries, R. S., Giglio, L., Randerson, J. T., Collatz, G. J., and Kasibhatla, P. S.: Estimates of fire emissions from an active deforestation region in the southern Amazon based on satellite data and biogeochemical modelling, Biogeosciences, 6, 235-249, doi:10.5194/bg-6-235-2009, 2009.

Wahyunto, Ritung, S., and Subagjo, H.: Peta Luas Sebaran Lahan Gambut danKandungan Karbon di Pulau Sumatera/Maps of Area of Peatland Distribution and Carbon Content in Sumatera, 1990-2002, Wetlands International - Indonesia Programme and Wildlife Habitat Canada (WHC), Bogor, 2003.
Wahyunto, Ritung, S., and Subagjo, H.: Peta Sebaran Lahan Gambut, Luas dan Kandungan Karbon di Kalimantan/Map of Peatland Distribution Area and Carbon Content in Kalimantan, 2000-2002, Wetlands International - Indonesia Programme and Wildlife Habitat Canada (WHC), Bogor, 2004.

Warner, B. G., Nobes, D. C., and Theimer, B. D.: An application of ground penetrating radar to peat stratigraphy of Ellice Swamp, southwestern Ontario, Can. J. Earth Sci., 27, 932-938, 1990.

Yu, Z., Loisel, J., Brosseau, D. P., Beilman, D. W., and Hunt, S. J.: Global peatland dynamics since the Last Glacial Maximum, Geophys. Res. Lett, 37, L13402, doi:10.1029/2010GL043584, 2010. 